\title{
Rebuilding subjectivity from the experience of cancer and its treatment
}

\author{
Reconstruindo a subjetividade a partir da experiência do câncer e seu tratamento \\ Reconstruyendo la subjetividad a partir de la experiencia del cáncer y su tratamiento
}

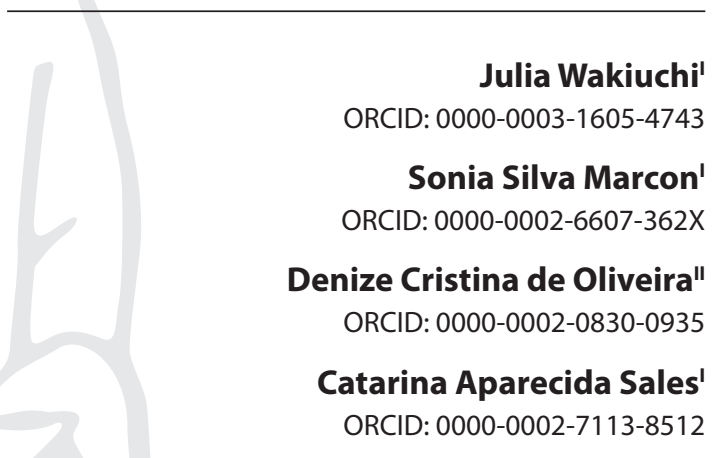

'Universidade Estadual de Maringá. Maringá, Paraná, Brazil. "Universidade do Estado do Rio de Janeiro. Rio de Janeiro, Rio de Janeiro, Brazil.

How to cite this article: Wakiuchi J, Marcon SS, Oliveira DC, Sales CA. Rebuilding subjectivity from the experience of cancer and its treatment. Rev Bras Enferm [Internet]. 2019;72(1):125-33. DOI: http://dx.doi.org/10.1590/0034-7167-2018-0332

\section{Corresponding Author: Julia Wakiuchi \\ E-mail: julia.wakiuchi@gmail.com

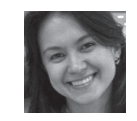

Submission: 05-10-2018

Approval: 07-28-2018

\section{ABSTRACT}

Objective: To analyze the social representations of chemotherapy and the experiences built by people with cancer. Method: Descriptive study with a qualitative approach. Data collection occurred between August and December 2016, through interviews with 29 cancer patients undergoing chemotherapy at an institution in the northern part of Paraná State, and the Thematic-Categorical Content Analysis. Results: Four categories have emerged denoting attitudes, feelings and experiences associated with chemotherapy and the need for reconstruction of daily life, permeated by the distancing of social life and work. At the same time, we note the close ties with friends and family, as well as adaptive strategies, new meanings of experiences lived and life priority setting. Final considerations: Cancer represents an interruption of plans and dreams, modifying everyday tasks and generating new experiences. This process facilitates giving a new meaning to the past and the reconstruction of subjectivity. Descriptors: Life Change Events; Neoplasms; Interpersonal Relations; Nursing; Qualitative Research.

\section{RESUMO}

Objetivo: Analisar as representações sociais do tratamento quimioterápico e as experiências construídas por pessoas com câncer. Método: Estudo descritivo, com abordagem qualitativa. A coleta de dados ocorreu entre agosto e dezembro de 2016, por meio de entrevistas com 29 pacientes com câncer em tratamento quimioterápico, em uma instituição no Norte do estado do Paraná, sendo realizada a Análise de Conteúdo Temático-Categorial. Resultados: Emergiram quatro categorias que denotam atitudes, sentimentos e experiências associados à quimioterapia e à necessidade de reconstrução do cotidiano, permeado pelo distanciamento da vida social e do trabalho. Ao mesmo tempo, nota-se o estreitamento de laços com amigos e familiares, além de estratégias adaptativas, de ressignificação das experiências vividas e de estabelecimento de prioridades de vida. Considerações finais: $O$ câncer representa uma interrupção dos planos e sonhos, modificando tarefas do cotidiano e gerando novas experiências. Esse processo oportuniza a ressignificação do passado e a reconstrução da subjetividade. Descritores: Acontecimentos que Mudam a Vida; Neoplasias; Relações Interpessoais; Enfermagem; Pesquisa Qualitativa.

\section{RESUMEN}

Objetivo: Analizar las representaciones sociales del tratamiento quimioterápico y las experiencias construidas por personas con cáncer. Método: Estudio descriptivo, con abordaje cualitativo. La recolección de datos ocurrió entre agosto y diciembre de 2016, a través de entrevistas con 29 pacientes con cáncer en tratamiento quimioterápico, en una institución en el Norte del estado de Paraná, siendo realizada la Análisis de Contenido Temático-Categorial. Resultados: Se plantearon cuatro categorías que denota actitudes, sentimientos y experiencias asociados a la quimioterapia y la necesidad de reconstrucción de lo cotidiano, impregnado por el distanciamiento de la vida social y del trabajo. Al mismo tiempo, se nota el estrechamiento de lazos con amigos y familiares, además de estrategias adaptativas, de resignificación de las experiencias vividas y de establecimiento de prioridades de vida. Consideraciones finales: El cáncer representa una interrupción de los planes y sueños, modificando tareas cotidianas y generando nuevas experiencias. Este proceso permite la resignificación del pasado y la reconstrucción de la subjetividad. Descriptores: Acontecimientos que Cambian la Vida; Neoplasias; Relaciones Interpersonales; Enfermería; Investigación Cualitativa. 


\section{INTRODUCTION}

Cancer is related to death in the lay and professional imaginaries, since the first reports of its existence ${ }^{(1)}$. Nowadays, both the aging population and the advance in the diagnostic accuracy have been contributing with the increase in the number of new cases of neoplasms; on the other hand, improved treatment has contributed to the longer survival of these patients ${ }^{(2)}$. The projections for the next 20 years point to the worldwide growth of about $60 \%$ of the cases, which reaffirms its status as a public health problem in intensification ${ }^{(3)}$.

Among the therapies adopted against cancer, chemotherapy stands out for personifying the image of the disease in the human being when transfiguring the body through the side effects ${ }^{(4)}$. The repercussions of chemotherapy come from its mechanism of action, which directly interferes with growth and tumor cell division and also from healthy tissues, which can be portrayed by changes in the patient's physical well-being ${ }^{(5)}$.

A review of the literature on the social representations of chemotherapy reveals that, for patients, the main repercussions of therapy are centered on their physical consequences, mainly alopecia, nausea, fatigue and malaise, which have unfavorable repercussions on the daily lives of the people involved ${ }^{(4)}$. In this context, chemotherapy can be a social object capable of generating representative processes, through which cognitive, behavioral and emotional strategies adapted to adaptation are organized, which help patients to experience the barriers of treatment ${ }^{(4)}$.

In this sense, the analysis of social representations about chemotherapy could benefit from a more in-depth view, drawn from the concept of experience ${ }^{(6)}$, in its articulation with the social, emotional and psychic context, which establishes itself from the beginning of chemotherapy for the person with cancer. The concept of experience, as defined by Jodelet $t^{(6)}$, is based on the way in which people inwardly feel a given situation and, from it, psychically and cognitively elaborate positive or negative representations, and also relate and perform actions in that context. Alongside the lived dimension, experience has a cognitive dimension, because it favors the construction of reality from socially known categories or socially known forms $s^{(6)}$.

The terms in which an experience is constructed and its correspondence with a given situation emerge from cultural pre-constructions and an accumulation of common knowledge that will give it form and content ${ }^{(6)}$. In this sense, the experience is articulated with the social representations, making possible the understanding of the human being in its affective, cognitive and social facets, which can be useful for a better understanding of the relations of people with the social world. The analysis of an experience can contribute to the enrichment of the approach and the social representations, as it includes aspects of the knowledge, the emotional dimension and the discursive language of the subject; considers its practices, contexts and the environment of life, besides allowing the observation of the subjectivity that emerges in the middle of the social context in which it is inserted ${ }^{(6)}$.

From this perspective, the diagnosis of cancer and the accomplishment of chemotherapy can constitute social phenomena, constructed and modified by those who experience it, which incites the following questioning: How do you configure the daily life and the experiences of cancer patients under chemotherapy? Knowing the feelings, attitudes, images, knowledge and wishes of these patients, from their experience can contribute to a reflection on the health care received by these subjects, aiming to offer a care focused to their needs. Therefore, the present study is justified as it seeks to understand the consensual universe of cancer patients who experience chemotherapy.

\section{OBJECTIVE}

To analyze the social representations of chemotherapy and the experiences built by people with cancer.

\section{METHOD}

\section{Ethical aspects}

The study was based on the doctoral thesis titled"Representações Sociais do Câncer e da Quimioterapia em Pessoas Adoecidas" of the Graduate Program in Nursing of the Universidade Estadual de Maringá. The project was approved by the Permanent Research Ethics Committee of the Universidade Estadual de Maringá.

\section{Type of study}

This is a descriptive study with a qualitative approach, based on the assumptions of the Social Representations Theory (SRT) (7). The SRT study can be considered as statements that surround common-sense "theories" or "collective sciences", which proceed to the interpretation and construction of social realities ${ }^{(7)}$.

\section{Methodological procedures}

\section{Study setting}

The study was carried out in a High Complexity Oncology Care Center (UNACON - Unidade de Assistência de Alta Complexidade), belonging to a regional hospital located in the north of Paraná State.

\section{Data source}

Participants were 29 cancer patients on outpatient chemotherapy, who met the following inclusion criteria: Present more than 18 years; be aware of the diagnosis of cancer, and have performed at least three months of chemotherapy. The invitations were held for convenience, when patients were waiting for chemotherapy after the medical appointment.

\section{Collection and organization of data}

For data collection, a sociodemographic form was used to characterize the participants, which contained data on marital status; schooling; work situation; source of income prior to illness and current; religious guidance and information sources on cancer and chemotherapy. Clinical data were also collected from 
the participants in the medical record, such as diagnosis, disease staging and treatment. For the interviews, a semi-structured script was used, which included questions related to the experiences during the chemotherapy and its attitude towards the same, the objective and subjective repercussions coming from this and their interpersonal and social relations from the treatment.

Data collection took place between August and December 2016, in a private practice provided by the institution, so that patients could express themselves in privacy. The interviews were recorded in a digital recorder and, afterwards, transcribed in their entirety by the researcher herself. The patients' anonymity was preserved from the codes (e1, e2, e3 ... e29), followed by the age and diagnosis of the interviewees.

\section{Data analysis}

All the material was submitted to Thematic-Categorical Content Analysis (ACTC - Análise de Conteúdo Temático-Categorial), considering its applicability in qualitative studies methodologically guided from eight steps: Quick or partially guided reading; definition of hypotheses; determination of Registration Units (RU); marking in the text of the beginning and end of each $\mathrm{RU}$; definition of Meaning Units (MU); thematic analysis of MU; categorical analysis of MU; and, finally, treatment and presentation of the results, besides the discussion of these results and return to the object of study ${ }^{(8)}$.

From these steps, four thematic categories were constructed that present the object reconstructed by the analysis and its articulation with the main references on cancer and chemotherapy in the present time and on the theoretical precepts of the social representations.

\section{RESULTS}

Among the 29 interviewees, 23 were female, 17 were Catholics, 27 were married or lived with their partner and 15 with incomplete Elementary School. Regarding the clinical characteristics, the most frequent type of cancer was the breast (15), and the diagnosis time ranged from three months to 19 years. Among those interviewed, 27 never had cancer recurrence, and 21 had no metastases. Most patients (17) underwent adjuvant antineoplastic therapy, in other words, performed after tumor resections, in order to increase survival.

The analysis of the interviews resulted in 526 Registration Units, distributed in 94 Meaning Units, which gave rise to four thematic categories presented below.

\section{Feelings and attitudes that permeate chemotherapy: The experiences with beginning of treatment}

The first category was the most expressive of the study, formed by 165 Registration Units, inserted in 35 Meaning Units. Faced with the various issues raised, patients reinforce their determination to perform chemotherapy, which is mandatory for the treatment of cancer, as demonstrated from the themes: "Treatment is a must" and "treatment will bring me life". The Registration Units below exemplify the themes:
[...] There is no way you have the disease and do not receive the treatment. How will you skip stages? I wouldn't risk being without it. (e023, 47 years old, breast cancer)

However, if it is a treatment to get well, what can you do? You need it, it is necessary, so there is no way, what can you do, right? (e056, 44 years old, breast cancer)

This treatment is bad in terms of malaise, but it is what is going to restore me. If it wasn't this treatment, maybe I wasn't here talking to you. So, I have to focus in what he is going to give me, life! ( $\mathrm{e} 025$, 52 years old, breast cancer)

It should be emphasized that the mention of chemotherapy refers to the previous information that people observed about it, reinforcing the images constructed by the common sense as "weak bald and Jaundice person", which is expressed in the feelings of fear and anguish, before even from the start of therapy. The intensity of the emotional repercussions, especially the anxiety before the treatment, can be demonstrated with the appearance of the side effects before the sessions of treatment, beginning until days before the moment of the applications of the medication. It is noteworthy that this theme was reported by 18 of the 29 patients interviewed:

And when he said chemotherapy I started to shake. But... You already think about that weak bald and Jaundice person. (e041, 19 years old, ovary cancer)

Some people told me that I would have nausea, I don't know what more. They just didn't say I was going to die. (e096, 56 years old, breast cancer)

When the days are about come, one, two, three days before to have chemotherapy, I feel a very great sadness, really great sadness. I feel like crying a lot, I get very depressed, but I think: I know it is to get well. (e022, 52 years old, breast cancer)

[...] This is what kills me. The day that I have to come, you see what your psychological is, I Wake up sick. So I feel nauseous all day, tomorrow it increases and later it gets normal. (e054, 41 years old, rectal cancer)

Their earlier references to chemotherapy make this experience frightening, yet recognized as indispensable to their lives.

\section{Experiencing relationships during chemotherapy: The experience of change}

The present category was composed of 160 Registration Units, grouped in 31 Meaning Units. The speeches portray a difficult social interaction after the beginning of chemotherapy, surrounded by a discriminatory process and behavior of withdrawal from the social environment, and the participant himself in relation to the others. Cancer appears to be represented as a transmissible disease, marked by the trait of contagion.

This situation has been portrayed in several themes, emphasizing: "I stopped having social life"; "People fall apart"; "They say you're going to die"; "The others look at you"; "They always 
ask"; "Nobody has anything good to tell you”; "It takes courage to leave home".

In the following RU it is possible to observe such changes in the interpersonal relations:

Many people, which before this disease treated us in a different way, now... You know, it seems like, I don't know, I think that they think that this disease pass on, it's something [...]. Even more now that I'm bald, it gets worse, you see that the person have that prejudice. (e067, 45 years old, thyroid cancer)

Sometimes, you find one and another that look at you and make that face. But is a face that I also made before, the people's face that isn't in this cancer world. You, me, everyone gets: - Wow, that person has cancer. (e043, 37 years old, breast cancer)

The participants also reported the difficulties that were installed in the familiar coexistence, after the beginning of the treatment, both of a practical and relational nature. The silence of the family seems to place itself in the place of confronting the disease and its treatment, making this experience solitary for those who live it. The main themes that emerged were: "Treatment shakes my whole family"; "My family cannot talk to me about my treatment"; "My children do not understand";"I undergo the treatment so that no one feels guilty"; and "I try to be strong to reassure my family". This can be seen in the following Registration Units:

[...] he [husband] couldn't let go, couldn't talk about the issue. Never: - Well, I'm going through this problem, What do you think, what do you feel about this? So, I already tried to talk to him, mas he doesn't... (e056, 44 years old, breast cancer)

[...] even if things don't go the way we planned, we know that everyone [Family] is doing what they can. So, sometimes we have these feelings that we can't even talk about, because you know that the person [brother] is going to be sad. (e066, 53 years old, breast cancer)

On the other hand, patients report the importance of support and affection expressed in interpersonal relationships during the course of treatment, revealing the need for the other and a support network, expressed by the themes: "Being close to the family is important"; "My family offers support"; "My friends offer support"; "Importance of friendship during treatment"; "During chemotherapy I met many people who help me"; "They treat me with more affection"; "My spouse is with me at all times".

Many friends. It helps a lot our friendship in this moment, the support, you know? In these moments you see who is your friend and who is not, just when you are sick. Because when you are well, in a dinner having a beer, everyone is your friend. But the moment when you get sick, you don't have anyone else. (e091, 61 years old, colon cancer)

It is hard to go through this, it is not easy, but I'm not alone, my husband always talks, he has, my brother, my mom, my daughter, they are in this battle with me. My mom, wow, she is my warrior, she lives with us. She takes care of my girl, because I'm like this [...]. The family's support is very important. (e098, 26 years old, Hodgkin's lymphoma)
In spite of the social and affective distances associated with the difficulty of talking about cancer with loved ones, patients were able to give friendships a new meaning and family ties, recognizing the importance of friends and maintaining a network of psychosocial support.

\section{Submitting to the new daily life and new experiences: Treatment repercussions and adaptation strategies}

This category presented $36 \%$ of the Registration Units, divided into 16 themes. Among the repercussions of the chemotherapy, which was the most representative for the patients, making up the largest number of RU of all the analysis (9.3\%), was the withdrawal from work and the financial difficulties. The patients emphasize that, despite seeking other sources of support, the difficulties of economic maintenance persist:

It is very difficult, we understand how much we miss work, it's so good to be working. It is so good to us and also to our pocket. Now we think that we miss, because sometimes you have to buy a drug, some things, and it is so hard. (e097, 48 years old, endometrial cancer)

So now I'm selling too, because I have nothing to do. The aid is $R \$ 780.00$ [Brazilian currency] and it's very little. You see, I pay the rent, I live with my daughter, my mom that helps me. You can't do something, you really can't. (e043, 37 years old, breast cancer)

Physical repercussions of chemotherapy also oblige patients to withdraw from normal activities, both at home and abroad, which has repercussions on a window of longer idle time that participants seek to fill. The themes "Adapting to the new routine after the start of chemotherapy" and "I cannot do what I did" portray the new daily life experienced by patients.

[...] I'm always laying down, watching TV or reading, I like a lot to read, I'm so lucky. I even take a medicine to nausea, which leaves me kind asleep, and then I spend my time like this. (e025, 52 years old, breast cancer)

[...] as I was bad, I slept a lot, so the times flew so fast, I spent the day. I turned on the TV, because I used to stay in the living room. I turned on the TV in the bedroom, let it on and I fell asleep, when I woke up, the tv show has already finished and another one has started, I just looked, turned aside and slept again. And this is how it was passing by. (e056, 44 years old, breast cancer)

In order to overcome the difficulties imposed by the treatment, patients create emotional, practical and social mechanisms to deal with their new daily life, which can be verified in a variety of subjects, mainly: "I try to see things the best way possible"; "Trying to live life normally"; "Faith is my source of strength"; "The family is my source of strength"; "Leisure is a form of relief"; and "Joy helps me to face the treatment".

I also seek refuge in my grandson, I really seek refuge in him. He is giving me the strenght, he really gives me a lot of strength [...] he is my refuge; it's in him that I find my strenght. (e022, 52 years old, breast cancer) 
It's a force that God gives us. We have to have a lot of confidence in God, in first place. Because God comes in first place, and then the doctors. (e023, 47 years old, breast cancer)

Encountering sources of encouragement and encouragement encourages continuity of treatment and helps patients alleviate the difficulties that chemotherapy entails. In this sense, despite the social and economic repercussions associated with therapy, patients try to divert their thoughts and actions to something that brings them comfort.

\section{Giving a new meaning to experiences: Subjective reper- cussions of chemotherapy}

This category was composed by 57 Registration Units and 12 Meaning Units meaning. The topic"Treatment as an opportunity to start again" was the most cited in the category, with $26 \%$ of RU, and discusses the reflection of the subjects about actions and judgments they had before starting the chemotherapy.

There are thing that I have done in life, which I know that it didn't Worth it, and I would have done different. I think that if I don't have passed through this, I wouldn't have this vision, you start to see life with another vision, in a different angle, it's different, it's different. (e054, 41 years old, rectal cancer)

[...] everything in life is a learning. Both good and bad things, we go... Especially the bad things, we learn with this. You see what you are doing wrong, and try to... see something good in it, in everything. (e085, 51 years old, breast cancer)

Other topics, such as "Between which I started thinking more about myself", "I am stronger now"; "Quality of life is a priority"; "I want to mark my presence" and "I cannot say no more" reveal the individual and subjective repositioning that the patients incorporated into their living after the beginning of treatment, in an attempt to feel better about themselves, as shown by RU:

First I think about myself, things that I didn't do: it was the others and I was al ways behind. Not now, now it is myself first. I changed in this part too: the priority now is me. (e022, 52 years old, breast cancer)

[...] early I was a little bit hooked in work, not today, today I give more importance to my health, I do my job as I can do it. If I have to lay down to rest, I will lay down to rest. (e085, 51 years old, breast cancer)

Also relevant to the participants were the themes: "I want to live more with my family"; "I want to enjoy my life more";"I want to miss you"; "I want to work less"; and "I want to help other people who do chemotherapy", which were all based on the desire to have different behaviors than planned before the illness and to take more advantage of the opportunities placed in their living. From these $\mathrm{RU}$, the patients reveal that the cancer and the chemotherapy awoke the thought in the finitude of the life and aided them in the unveiling of important facets of their living:

It's living, living and trying to do something in life to others, which sometimes we don't do. Be more with Family [...] try to live with your relatives, try to enjoy in a healthy way what I couldn't before. (e066, 53 years old, breast cancer)

There are things that today I think: why I didn't Wake up early? I always try to give my best, the best... But the best is being together, is giving love, knowing that they are important in your life, despite I think they know that... So, that's it. God allowed me that I could see again that is not just the job. (e025, 52 years old, breast cancer)

Finally, the themes: "Living each day as the last" and "I am ready for death", demonstrate that before the concrete possibility of death, patients abandon activities and plans, failing to build expectations for the distant future.

You start to go to sleep, because you don't know if you are going to Wake up in the other day. And when you Wake up, you thank for being here one more day. So, I'm like this, living every day if it's the last. (e056, 44 years old, breast cancer)

Their experiences, based on this thought, are based on the attempt to value life and the moments they still have, focusing on moments that have meaning for themselves.

\section{DISCUSSION}

The analysis of the social representations of the chemotherapy with the daily experiences of people with cancer made it possible to observe the changes in social and individual life for the participants, as well as their interpersonal and family relationships after illness, highlighting intrinsic needs for adaptation. As active social actors, these men and women were "affected by different aspects of everyday life, which develops in a social context of interaction and inscription", permeating communication and social belonging, their place in this structure, in social relations, their insertion into groups, and their context of life in social and public space ${ }^{(9)}$.

Although in the studies of social representations the elements under analysis are shared by the groups, it is important to consider the processes of appropriation and construction of representations at the individual level, considering the subjectivity of each person ${ }^{(9)}$. These processes depend on the experience of individual life, since they are established from their body, sensibility and emotions, which are added to the cognitions and knowledge acquired or constructed throughout life, at a social level ${ }^{(10)}$.

Given this context, it is important to emphasize the curative and life-sustaining dimension attributed to chemotherapy, which is a successful treatment for many cases of neoplasms. Chemotherapy is responsible for increasing the life expectancy of cancer patients and for quality of life, representing advances in both control and cure of the disease ${ }^{(11)}$. The recognition of chemotherapy as beneficial in the fight against cancer helps the construction of judgments and attitudes on the part of the patients, who are in favor position to the accomplishment of the same, without great questions. The expected benefits outweigh its barriers, marked by the severity of the side effects that arise from the beginning of treatment.

On the other hand, previous information on chemotherapy refers to stigmas and images constructed based on the physical repercussions caused by the drugs. Thus, the person with alopecia, 
emaciated and weak, personifies chemotherapy and cancer, which is part of a process of recognition of the disease and suffering caused by therapy and society. This figure is repeated every cycle of medicines, building individual and social experiences.

This imaging construction also has repercussions on the interpersonal relationships after the beginning of chemotherapy, denoting the prejudice that originates in the person with cancer and also in the social life in general. This is because the physical changes from the therapy are easily identified - the hair fall - which causes the patient to see the attention and the looks that he will receive in public places, to avoid such situations ${ }^{(12)}$. The body is an enclosure of participation in the world and in subjectivity, considering that man is situated in the world through his body and every thought belongs to a corporeality ${ }^{(9)}$. In this sense, the patient's concern to expose himself / herself to others, as a person with cancer, has a substantial impact on the reduction of their interpersonal relationships and consequent social isolation ${ }^{(12)}$.

As far as family coexistence is concerned, there is an affective dimension, from which two important tendencies are established: Difficulties in relationships and coexistence as a result of the changes caused by illness and onset of antineoplastic treatment, in contrast to the importance of support and family affection. It is emphasized that the emotional manifestations experienced by the cancer patient express the need for protection and protection, which is demanded by subjects who already occupy this role in their lives, with emphasis on the family ${ }^{(13-14)}$.

However, the family also goes through moments of restructuring and need for care, because the process of accompanying a family member with cancer instigates reflection on finitude, which may result in difficulty in communicating with the patient who is $\mathrm{ill}^{(13)}$. This condition was reported by the patients in this study, who visualized in their families the stigma of death linked to cancer and the difficulty of talking about finitude. In this sense, the fear of death is reflected in the elusiveness in talking about it on the part of the relatives, and in the search for an emotional stability by the patients, who try not to transmit their sufferings and dissatisfactions to the family.

Allied to this, objective repercussions also settle in the patient's life under chemotherapy, especially the withdrawal of work and the consequent financial impact that is installed as a result, putting them in a new cycle of experiences and the construction of a new subjectivity. The decrease in income, associated to the increase in expenses with food and medicines, has an impact on family income, which has already been evidenced in Brazilian and international studies ${ }^{(12,15-16)}$. In addition, leaving work creates obstacles in social relationships and daily activities, because work also constitutes a social environment of interaction ${ }^{(16)}$.

Staying in the home after the beginning of treatment is a consensus in patients' discourses, which describe an empty daily life, and try to rebuild it with activities that occupy their time and their thoughts. These findings corroborate studies with patients undergoing antineoplastic treatment that demonstrated the limits that are installed in the life of these subjects, mainly due to physical incapacity and exhaustion, which prevents them from performing daily tasks ${ }^{(17-18)}$.

In fact, a new cycle of experiences and the constitution of subjectivity is instituted from the beginning of chemotherapeutic therapy, which requires the reconstruction of everyday reality, the knowledge, attitudes and behaviors of the patients, who become responsible, for their health and quality of life ${ }^{(19)}$. The meaning of an experience permeates intervention on social representations, be they individual, social or collective, contributing to the change of subjectivity ${ }^{(9)}$. Thus, it is stated that the antineoplastic treatment entails cumulative and interrelated losses of the people who experience it, that is, at the same time as there is a deficit in the functional and health status, it also modifies their physical appearance, professional identity, affective relationships, among others, that end up compromising their personal well-being ${ }^{(20)}$.

In this sense, coping with daily life becomes a challenge for the patient under chemotherapy, which needs support and affection during this process. The presence of the family was considered beneficial by the patients, source of refuge and security during the difficulties. In addition, faith was pronounced as determining for the understanding of the moment they are experiencing. Other studies have already mentioned religiosity and spirituality as strategies to support and comfort the subjects with cancer, since they provide them with serenity and understanding to face the disease, as well as belief in a superior being who unconditionally supports them during the course of the disease ${ }^{(18,21-23)}$.

As far as spirituality is concerned, it is important to emphasize its implication in the changes of life perspective that can occur in the patient due to cancer, mainly in the need of transcendence and a new meaning of the reality that surrounds $i^{(21)}$. For the participants of this study, the subjective repercussions during chemotherapy were expressed, in the first instance, in the perception of a starting point in their lives, in order to refer to chemotherapy as a moment of intense suffering that ends up provoking learning and reflection about the past.

In the meantime, changes in the patients' reality during the course of chemotherapy may alter their view on existence, their individual strength and valorization, and the prioritization of quality of life, which is reflected in the expectation of a new life after all the mishaps experienced during the cancer. Similar results were evidenced in a study conducted in the United States, which also found a change in the personal strength of the patients, based on reports of greater emotional maturity and psychological confidence after neoplasms ${ }^{(23)}$. In the face of difficulties, these patients began to appreciate more what, before the illness seemed obvious; thus, health, family and life gain new meanings and esteem ${ }^{(21)}$.

Finally, the perception of patients who, facing the possibility of death, try to live the present reality in the best way, with the aim of expressing gratitude for what they have gone through and seeking the courage to confront the difficult reality imposed on them. The resignation with the situation lived by the patients with cancer, already evidenced in the literature, helps the subject to adapt to the lived reality, facing and understanding better his situation $^{(24)}$. On the other hand, the reference to the finitude of life reiterates the representation of cancer anchored in death, still present in the social imaginary ${ }^{(21)}$.

In general, the patients' experiences under chemotherapy are based on references to cancer, permeating attitudes towards chemotherapy, the feelings that emerge when starting the treatment and its repercussions on interpersonal relations, and 
also the adaptation to the new daily life. Chemotherapy consists of an interruption of life, of plans and dreams, modifying each task of daily life prior to illness. On the other hand, antineoplastic therapy causes a subjective impact on the cancer patient, which influences the reconstruction of future perspectives, representing, in this sense, an opportunity to live, to restore ties and correct past mistakes, as a point of resumption of their existence.

Taking into account the subjectivity of the subjects in their symbolic constructions denotes the expressive function of social representations, which "are always from someone"(9). Such an analysis allows access to the meanings that people attribute to the object, and thus to analyze how these meanings are articulated to their cognitive functioning in regard to interests, desires and emotions ${ }^{(9)}$.

The affective and relational aspects that are installed in the participants' lives during the chemotherapy permeated their discourses, however, no concepts or information on chemotherapy were expressed, which suggests the non-structuring of a social representation or, still, a social representation in process of formation. It is important to consider that, according to Moscovici ${ }^{(7)}$, the organization of a representation is based on the existence of three essential elements: the attitude or global guidance towards the object, that is, the judgment before chemotherapy; the information, in this case, related to the organization of knowledge that the group has about chemotherapy; and the field of representation or image, which is expressed through a social model constructed before the propositions of specific aspects about the object under study.

It is observed the non-favoring of access to the reified knowledge about the object being studied. Possibly, the sharing of scientific and technical knowledge about treatment by health professionals did not result in the incorporation of this knowledge by the subjects, which resulted in the construction of consensual knowledge based on experiences and translations of the patients themselves. In addition, analyzing the categories constructed in this study, it is possible to suggest that the health team, especially the nursing team, could act positively on the daily repercussions of chemotherapy, in order to offer information that helps to concretely experience the cancer for the patient and his family.

\section{Study limitations}

As a limitation of the study, the regional setting, which contemplates only one service, is based on a social group that experiences a peculiar health care context: a new service that is structured as a regional reference and has specific characteristics. In any case, its construction indicates the need for practical improvement for nursing, seeking the accomplishment of an assistance that contemplates individual and social needs of the patient with cancer.

\section{Contributions to the area of Nursing}

The results presented here are important for nursing, in the sense that patients have few subsidies for the construction of representations about chemotherapy, and admit their non-participation regarding therapeutic decisions, up-to-date information and greater knowledge about their treatment, transforming the experience of chemotherapy into an individual and little shared process.

Thus, the process of stigmatizing cancer, which is established historically and culturally, could gain new shape if real information on cancer and chemotherapy was disseminated by the media and health professionals. From the access to reified knowledge, gradually, patients could become familiar with chemotherapy, creating concepts, images and attitudes about this object, in order to organize it as a social representation.

\section{FINAL CONSIDERATIONS}

The results of this study show the complex relationships between perceptions about the chemotherapy and the daily life of individuals with cancer, and about their interpersonal and family relationships. Social detachment is evident, permeated by a process of detachment that is established by the discrimination of the person with cancer, by the difficulty in participating in collective activities and by their own isolation before the physical repercussions of the disease and its treatment. In the meantime, there is also a close relationship of trust, affection and loyalty with close relatives and friends, who give strength and courage to patients for the continuity of treatment, as well as individual and subjective changes that incite them to rebuild their lives after the mishaps that the treatment imposes.

The non-organization of a social representation of chemotherapy, considering the predominance of affective contents observed in the study, especially those related to the attitudes towards the treatment and references to its effects, is only a reproduction of the reality lived during chemotherapy. Possibly, these patients did not receive enough information about the treatment, nor did they seek further clarification, organizing their perceptions based on experiences and feelings.

It is considered that the ability to cope with chemotherapy based on scientific knowledge from the reified universe could help patients to experience better treatment and adverse reactions. Thus, the physical and emotional repercussions that affect patients even before chemotherapy, besides the looks and words that affect them and modify their social life, could be improved or better understood, considering the appropriation of knowledge about their illness, treatments and prognosis. In addition, such a condition could provide a better management of the symptoms of the treatment and, consequently, the performance of plans according to the therapeutic possibilities, the understanding of the benefits and repercussions of chemotherapy, as well as the use of time with friends and family, with a view to improving the quality of life of patients undergoing chemotherapy.

\section{FUNDING}

The present work was carried out with the support of the Coordination of Improvement of Higher Education Personnel - Brazil (CAPES - Coordenação de Aperfeiçoamento de Pessoal de Nível Superior) - Financing Code 001. 


\section{REFERENCES}

1. Lerner K, Vaz P. ["My story of overcoming": suffering, testimony and therapeutic practices in cancer narratives]. Interface (Botucatu) [Internet]. 2017 [cited 2018 Jan 18];21(61):153-163. Available from: http://dx.doi.org/10.1590/1807-57622015.0822 Portuguese.

2. DeSantis CA, Lin CC, Mariotto AB, Siegel RL, Stein KD, Kramer JL et al. Cancer treatment and survivorship statistics, 2014. CA Cancer J Clin [Internet]. 2014 [cited 2018 Jan 18];64(4):252-271. Available from: http://dx.doi.org/10.3322/caac.21235

3. Saracci R, Wild CP. Fifty years of the International Agency for Research on Cancer. Int J Cancer [Internet]. 2016 [cited 2018 Jan 18];138(6):1309-11. Available from: http://dx.doi.org/10.1002/ijc.29929

4. Rodríguez AMC, Palácios-Espinosa X. Social representations of cancer and chemotherapy. Psicooncología. 2013;10(1):79-93. doi: 10.5209/ rev_PSIC.2013.v10.41949

5. Freitas BN, Neves JB. Efeitos colaterais da quimioterapia: os sentimentos apresentados pelos homens em tratamento. Rev Enferm Integrada [Internet]. 2013 [cited 2018 Jan 18]; 6(1):1064-73. Available from: https://www.unilestemg.br/enfermagemintegrada/artigo/v6/04-efeitoscolaterais-da-quimioterapia-os-sentimentos-apresentados-pelos-homens-em.pdf

6. Jodelet $\mathrm{D}$. Place de l'expérience vécue dans le processus de formation des représentations sociales [Internet]. Rennes: Les Press Universitaire de Rennes; 2006 [cited 2018 Nov 3]. 33 p. Available from: http://classiques.uqac.ca/contemporains/jodelet_denise/place_experience_ processus/place_experience_processus.pdf French.

7. Moscovici S. A psicanálise, sua imagem e seu público. Petrópolis: Vozes, 2012. 456 p.

8. Oliveira DC. Análise de Conteúdo Temático-Categorial; uma técnica maior nas pesquisas qualitativas. In: Lacerda MR, Constenaro RGS. Metodologias de Pesquisa para Enfermagem e Saúde: da teoria à prática. Porto Alegre (RS): Moriá; 2016.

9. JJodelet D. [The return to the notion of subject and the approach of social representations]. Soc Estado [Internet]. 2009 [cited 2018 Jan 18];24(3):679-712. Available from: http://dx.doi.org/10.1590/S0102-69922009000300004 Portuguese.

10. Jodelet D. Psychosocial problems of the investigation on the concept of subject. Cad Pesq [Internet]. 2015 [cited 2018 Jan 18];45(156):31427. Available from: http://dx.doi.org/10.1590/198053143203

11. Gozzo TO, Souza SG, Moysés AMB, Carvalho RAOC, Ferreira SMA. Knowledge of a nursing team about chemotherapy adverse effects. Ciênc Cuid Saúde [Intenet]. 2015 [cited 2018 Jan 18];14(2):1058-66. Available from: doi: 10.4025/cienccuidsaude.v14i2.25040

12. Kuo CY, Liang SY, Tsay SL, Wang TJ, Cheng SF. Symptom management tasks and behaviors related to chemotherapy in Taiwanese outpatients with breast cancer. Eur J Oncol Nurs [Internet]. 2015 [cited 2018 Jan 18];19(6):654-9. Available from: http://dx.doi.org/10.1016/j. ejon.2015.03.012

13. Sette CP, GradvohI SMO. [Emotional experiences of cancer patients undergoing chemotherapy]. Rev Psicol UNESP [Internet]. 2014 [cited 2018 Jan 18];13(2):26-31. Available from: http://pepsic.bvsalud.org/pdf/revpsico/v13n2/a03.pdf Portuguese.

14. Beaver K, Williamson S, Briggs J. Exploring patient experiences of neo-adjuvant chemotherapy for breast cancer. Eur J Oncol Nurs [Internet]. 2016 [cited 2018 Jan 18];20:77-86. Available from: http://dx.doi.org/10.1016/j.ejon.2015.06.001

15. Li Q, Lin Y, Qiu Y, Gao B, Xu Y. The assessment of a health-related quality of life and related factors in Chinese elderly patients undergoing chemotherapy for advanced cancer: A cross-sectional study. Eur J Oncol Nurs [Internet]. 2014 [cited 2018 Jan 18];18(4):425-35. Available from: http://dx.doi.org/10.1016/j.ejon.2014.03.005

16. Schmidt AM, Hahn GV. Qualidade de vida de pacientes em tratamento quimioterápico. Destaques Acad [Internet]. 2014 [cited 2018 Jan 18];6(3):107-16. Available from: http://www.univates.br/revistas/index.php/destaques/article/viewFile/421/413

17. Gassmann C, Kolbe N, Brenner A. Experiences and coping strategies of oncology patients undergoing oral chemotherapy: first steps of a grounded theory study. Eur J Oncol Nurs [Internet]. 2016 [cited 2018 Jan 18];23:106-14. Available from: http://dx.doi.org/10.1016/j. ejon.2016.06.001

18. Silva SED, Araújo JS, Chaves MO, Vasconcelos EV, Cunha NMF, Santos RC. Social representations about the disease of women with cervicouterine cancer. J Res Fundam Care [Internet]. 2016 [cited 2018 Jan 18];8(1):3667-78. Available from: http://dx.doi.org/10.9789/21755361.2016.v8i1.3667-3678

19. Conceição VM, Silva SED, Pinheiro SC, Santana ME, Araujo JS, Santos LMS. Social Representations about chemotherapy for oncology customers. Tempus [Internet]. 2012 [cited 2018 Jan 18]; 6(3):83-99. Available from: doi: 10.18569/tempus.v6i3.1157 Portuguese.

20. Mosher CE, Johnson C, Dickler M, Norton L, Massie MJ, DuHamel K. Living with metastatic breast cancer: a qualitative analysis of physical, psychological, and social sequelae. Breast [Internet]. 2013 [cited 2018 Jan 18];19(3):285-92. Available from: http://dx.doi.org/10.1111/ tbj.12107

21. Palacios-Espinosa X, Zani B. Social representations of cancer and chemotherapy in cancer patients. Diversitas Perspect Psicol [Internet]. 2014 [cited 2018 Jan 18];10(2):207-223. Available from: http://www.scielo.org.co/pdf/dpp/v10n2/v10n2a03.pdf

22. Dyer KE. "Surviving is not the same as living": cancer and sobrevivencia in Puerto Rico. Soc Sci Med [Internet]. 2015 [cited 2018 Jan 18];132:20-9. Available from: http://dx.doi.org/10.1016/j.socscimed.2015.02.033

23. Zamora ER, Yi J, Akter J, Kim J, Warner EL, Kirchhoff AC. 'Having cancer was awful but also something good came out': post-traumatic growth 
among adult survivors of pediatric and adolescent cancer. Eur J Oncol Nurs [Internet]. 2017 [cited 2018 Jan 18];28:21-27. Available from: http://dx.doi.org/10.1016/j.ejon.2017.02.001

24. Leitão BFB, Duarte IV, Bettega PB. [Patients with cancer of oral cavity undergoing surgery: social representations about the treatment]. Rev SBPH [Internet]. 2013 [cited 2018 Jan 18]; 16(1):113-40. Available from: http://pepsic.bvsalud.org/scielo.php?script=sci_arttext\&pid =S151608582013000100007 Portuguese. 